\title{
Guidelines for adults
}

\author{
Paul Telfer
}

Barts and The London Children's Hospital, London, UK

\section{Background}

Sickle Cell Disease is a rare condition in many regions of Europe and general clinicians responsible for local services to patients with SCD may have relatively little experience and knowledge of the condition. Inadequate and inappropriate management may deprive patients of treatments and support shown to be beneficial, and may result in sub-optimal outcomes in the short and long-term. A recent report of fatal outcomes in patients with haemoglobin disorders in the UK (National Confidential Enquiry into Patient Outcome and Death, 2008) has highlighted a number of cases where mortality could have been avoided by adherence to standard guidelines or protocols.

\section{General considerations}

Local, national, and international guidelines need to take into account differences in health care systems, accessibility and availability of resources. Obviously guidelines for resource-poor, high prevalence countries in sub-Saharan Africa cannot be the same as those for developed countries. Pan European guidelines may be difficult to implement in individual countries because of the variability in health care systems and differing demographics, health care priorities, and funding arrangements. Local guidelines need to be specifically tailored to the local services and local patient group, and would normally be an adaptation of a national guideline.

The main purposes of guidelines include: Informing and assisting health care workers in delivering accepted standards of care, facilitating management of quality of clinical services (e.g. through use in formulating clinical audit standards and peer review of services). They may also form part of a framework for commissioning of health care services, and guide patients in understanding what management they should be receiving.

Correspondence: Paul Telfer

CC Copyright P. Telfer, 2013

Licensee PAGEPress, Italy

Thalassemia Reports 2013; 3(s1):e29

doi:10.4081/thal.2013.s1.e29

This article is distributed under the terms of the Creative Commons Attribution Noncommercial License (by-nc 3.0) which permits any noncommercial use, distribution, and reproduction in any medium, provided the original author(s) and source are credited.

Parts of this work were presented at the

" $3^{\text {rd }}$ Pan-European Conference on Haemoglobinopathies and Rare Anaemias", Limassol (Cyprus), 24-26 October 2012.
Developing guidelines usually starts with identification of a need, and then an act of commissioning from a regulatory or professional body, and often also from a recognised patient/user group. In the UK, the Thalassaemia and Sickle Cell Societies were involved in developing national guidelines from the outset, and in initiating the process of guideline development.

The development of guidelines requires appointment of a chairperson/lead and an expert panel, which should include a range of expert health care workers (not just specialist doctors: Nurses, psychologists, laboratory scientists etc all need to contribute if the guidelines are to represent the multi-disciplinary nature of care). User representatives must be included on the panel. Competing interests of the panel members must be formally declared and considered carefully, as these may influence the objectivity of the final document.

The process includes deciding on the scope of care are to be covered. This is followed by a literature review, with grading of evidence, then drafting, review of draft, putting the draft out for comments from a range of non-panel experts, redraft and approval of final draft by commissioning/professional organization.

\section{Evidence base for SCD guidelines}

In the case of SCD, the optimal evidence for clinical interventions, i.e. well designed and conducted randomised controlled trials (RCT's), is relatively sparse. Below is a list of completed RCT's which have influenced clinical practice in SCD:

\section{Pneumococcal prophylaxis with oral penicillin}

PROPS 1 and 2: Penicillin prophylaxis recommended for children with SCD at least until age $5 .(1,2)$

\section{Hydroxyurea}

MSH, Baby HUG. Hydroxyurea significantly reduces frequency and severity of acute painful crisis and acute chest crisis, and is recommended for adults with a history of frequent crises. $(3,4)$

\section{Transfusion}

Pre-operative transfusion in sickle study group: Top-up transfusion is as effective as exchange in preventing surgical complications and resulted in fewer transfusion-related complications. TAPS: Pre-operative transfusion results in fewer adverse events than no transfusion $(\mathrm{J}$ 
Howard et al., submitted for publication). Pre-operative top-up transfusion is recommended for patients with SCD ( $\mathrm{HbSS}, \mathrm{HbS}$ beta zero thalassaemia) undergoing moderate to high intensity surgical procedures. (5)

\section{Iron chelation}

Deferasirox is a safe alternative to desferrioxamine and has similar efficacy. (6)

\section{Pain}

Oral versus i.v. morphine. Oral short and long-acting morphine is as effective as i.v. morphine in managing children with acute painful crisis, once initial i.v. bolus has been given. (7).

\section{Primary stroke prevention}

STOP 1 and 2. Regular transfusion to maintain $\mathrm{Hbs}<30 \%$ significantly reduces the risk of stroke in children with abnormal transcranial Doppler (TCD) velocities. $(8,9)$ Services are recommended to implement the STOP protocol of regular TCD screening and long-term transfusion of children with SCD (HbSS and HbS beta zero thalassaemia) and abnormal TCD.

\section{Secondary stroke prevention}

SWiTCH. Switching from transfusion (and chelation) to hydroxyurea (and venesections) is associated with a significantly higher risk of recurrent stroke compared to continuing transfusions. (10) Patients with a history of ischaemia stroke should continue on long-term transfusion.

\section{Pregnancy}

Regular transfusions decrease the frequency of painful crises, but do not impact on obstetric or perinatal outcomes. Transfusion is not recommended as routine practice during pregnancy. (11)

\section{Scope of guidelines for SCD}

It is clear that this evidence base does not cover the entirety of SCD care, and comprehensive guidelines need to take into account other published evidence from non-randomised trials, cohort studies, case series and expert opinion. Guidelines should cover the following domains of care:

\section{Acute and chronic pain management}

Acute complications: Acute Chest syndrome, Biliary problems, priapism, multiorgan failure, sepsis, acute anaemic episodes, ischaemic and haemorrhagic stroke etc.
Chronic complications: Chronic renal insufficiency, pulmomary hypertension, chronic sickle lung syndrome, avascular necrosis of joints and skeleton, retinopathy, lower limb ulceration, liver disease, heart disease etc.

Blood transfusion, exchange transfusion, iron chelation.

Hydroxyurea, bone marrow transplantation, new therapies.

Regular monitoring and annual review.

Surgery.

Pregnancy, contraception, fertility.

Psychological and social support.

User involvement.

Organization and commissioning of services.

\section{What is the current status of national/international guidelines for adults with SCD?}

Examples include:

- UK- National Guidelines published in 2008 (accessible at: http://sct. screening.nhs.uk/)

- France- National Guidelines published in 2010 (accessible at: http:// www.has-sante.fr/portail/upload/docs/application/pdf/201004/ald_10_guide_drepano_adulte_web.pdf),

- USA: NIH-sponsored guidelines published 2002, update expected in 2012 (accessible at: http://www.nhlbi.nih.gov/health/prof/blood/ sickle/sc_mngt.pdf)

- Europe: ENERCA Workpackage 4 'Public Health Issues and management of patients with SCD', Paediatric guideline has been published and work is progressing on an adult guideline.

\section{References}

1. Gaston MH, Verter JI, Woods G, et al. Prophylaxis with oral penicillin in children with sickle cell anemia. A randomized trial. N Engl J Med. 1986;314:1593-1599.

2. Falletta JM, Woods GM, Verter JI, et al. Discontinuing penicillin prophylaxis in children with sickle cell anemia. Prophylactic Penicillin Study II. J Pediatr. 1995;127:685-690.

3. Charache S, Terrin ML, Moore RD, et al. Effect of hydroxyurea on the frequency of painful crises in sickle cell anemia. Investigators of the Multicenter Study of Hydroxyurea in Sickle Cell Anemia. N Engl J Med. 1995;332:1317-1322.

4. Wang WC, Ware RE, Miller ST, et al. Hydroxycarbamide in very young children with sickle-cell anaemia: a multicentre, randomised, controlled trial (BABY HUG). Lancet;377:1663-1672.

5. Vichinsky EP, Haberkern CM, Neumayr L, et al. A comparison of conservative and aggressive transfusion regimens in the perioperative management of sickle cell disease. The Preoperative Transfusion in Sickle Cell Disease Study Group. N Engl J Med. 1995;333:206-213.

6. Vichinsky E, Onyekwere 0, Porter J, et al. A randomised comparison of deferasirox versus deferoxamine for the treatment of transfusional iron overload in sickle cell disease. $\mathrm{Br} \mathrm{J}$ Haematol. 2007;136:501-508.

7. Jacobson SJ, Kopecky EA, Joshi P, Babul N. Randomised trial of oral morphine for painful episodes of sickle-cell disease in children. Lancet. 1997;350:1358-1361.

8. Adams RJ, McKie VC, Hsu L, et al. Prevention of a first stroke by transfusions in children with sickle cell anemia and abnormal 
results on transcranial Doppler ultrasonography. N Engl J Med. 1998;339:5-11.

9. Adams RJ, Brambilla D. Discontinuing prophylactic transfusions used to prevent stroke in sickle cell disease. $\mathrm{N}$ Engl $\mathrm{J}$ Med. 2005;353:2769-2778.
10. Ware RE, Helms RW. Stroke With Transfusions Changing to Hydroxyurea (SWiTCH). Blood;119:3925-3932.

11. Koshy M, Burd L, Wallace D, Moawad A, Baron J. Prophylactic redcell transfusions in pregnant patients with sickle cell disease. A randomized cooperative study. N Engl J Med. 1988;319:1447-1452. 